\title{
Synthesis of Indoles by Domino C/N-Arylation of Azaallylic Anions
}
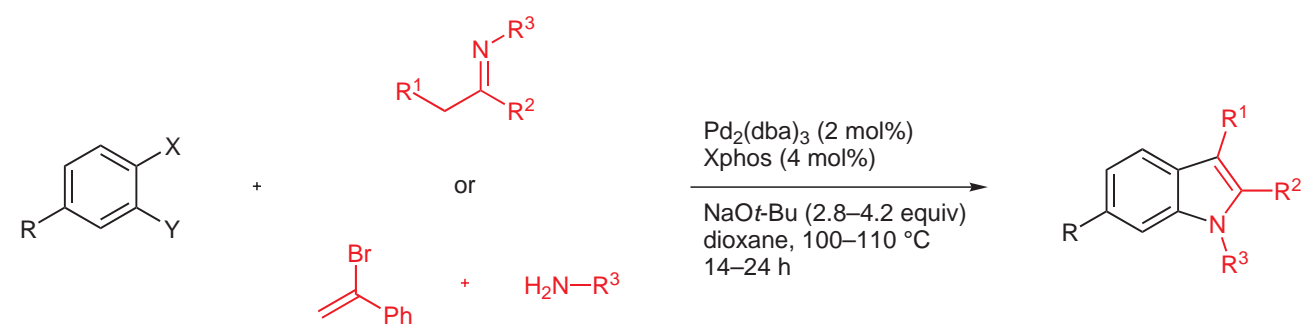

$\mathrm{X}=\mathrm{Cl}, \mathrm{Br} ; \mathrm{Y}=\mathrm{Cl}, \mathrm{Br}, \mathrm{I}$

19 examples

$\mathrm{R}=\mathrm{H}, \mathrm{OBn}$

$56-86 \%$

$\mathrm{R}^{1}=\mathrm{H}, \mathrm{Me}, n-\mathrm{Bu}$

$\mathrm{R}^{2}=\mathrm{Me}, n$-Pent, $\mathrm{Ph}, 4-\mathrm{MeOC}_{6} \mathrm{H}_{4}$

$\mathrm{R}^{3}=t-\mathrm{Bu}, \mathrm{Bn}, \mathrm{Ph}, 4-\mathrm{MeOC}_{6} \mathrm{H}_{4}, 2-\mathrm{ClC}_{6} \mathrm{H}_{4}$

$\mathrm{R}^{1}-\mathrm{R}^{2}=\left(\mathrm{CH}_{2}\right)_{3},\left(\mathrm{CH}_{2}\right)_{4},\left(\mathrm{CH}_{2}\right)_{5}$

Significance: A new reasonably efficient method for the synthesis of indoles utilizing an azaallylic anion equivalent, generated by imine deprotonation that undergoes chemoselective $\mathrm{C}$-arylation followed by intramolecular $\mathrm{N}$-arylation, is reported. Extraordinarily, the overall process may be carried out as a three-component reaction via generation of imine from an in situ $\mathrm{C}-\mathrm{N}$ coupling of styryl bromide with a primary amine. Bulky and electron-rich monophosphines function best as ligands and regioselectivity based on the expected rates of oxidative addition is observed using simple and commercially available dihaloarenes. Unsymmetrical dialkyl imines give regioisomeric products with modest selectivities (favoring C-arylation with the less-substituted available azaallylic anion prior to $\mathrm{C}-\mathrm{N}$ coupling), a direct contrast in terms of the regiochemistry which is observed in the Fischer indole synthesis under standard conditions (D. Zhao, D. L. Huges, D. R. Bender, A. M. DeMarco, P. J. Reider J. Org. Chem. 1991, 56, 3001-3006).
Comment: This chemistry is a continuing theme in the Barluenga group for the regioselective preparation of substituted indoles (J. Barluenga, M. A. Fernández, F. Aznar, C. Valdéz Chem. Eur. J. 2005, $11,2276-2283)$ and is an important contribution to a recently blooming field of $\mathrm{Pd}$-catalyzed cascade processes (A. Fayol, Y.-Q. Fang, M. Lautens Org. Lett. 2006, 8, 4203-4206) for the regioselective synthesis of privileged indole heterocycles. 